\title{
Understanding Grootboom - A Response to CASS R. SUNSTEIN
}

\author{
Theunis Roux
}

\section{INTRODUCTION}

In a typically thought-provoking essay on the significance of the recent judgment of the South African Constitutional Court in Grootboom, ${ }^{1}$ Cass R. Sunstein welcomes the contribution of this "extraordinary decision" to the international debate over the justiciability of socio-economic rights. ${ }^{2}$ In particular, he argues that the decision provides a partial answer to the objection that the judicial enforcement of such rights inevitably requires courts to assume "an unacceptable managerial role." 3 On Professor Sunstein's reading, the Court in Grootboom successfully steers a middle course between the Scylla of complete enforceability and the Charybdis of nonjusticiability. It does so by adopting what is in effect an "administrative law model of socio-economic rights," one which reads such rights as giving courts the power to order government to "devote more resources than it otherwise would" to the regulatory problem at issue. ${ }^{4}$

The further significance of the Grootboom decision, according to Professor Sunstein, is that the outcome required the South African government to pay

close attention to the human interests at stake and sensible priority-setting, without mandating protection for each person whose socio-economic needs are at risk. The distinctive virtue of [this approach] is that it is respectful of democratic prerogatives and of the limited nature of public resources, while also requiring special deliberative attention to

Government of the Republic of South Africa v. Grootboom 2000 (11) BCLR 1169 (CC), 2001 (1) SA 46 (CC) [hereinafter Grootboom].

2 C.R. Sunstein, "Social and Economic Rights? Lessons from South Africa" (2001) 11:4 Const. For. 123.

Ibid. at 123 .

$4 \quad$ Ibid. those whose minimal needs are not being met. ${ }^{5}$

It is always gratifying to have jurisprudential developments in one's own country put into a broader perspective in this way. ${ }^{6}$ South African commentators, preoccupied as they are with their sectoral concerns, often find it difficult to stand back from a decision like Grootboom in order to assess its true significance. By the same token, however, local commentators precisely because of their concern for the practical impact of such cases - are more alert to, or at least more inclined to see, their possible weaknesses. ${ }^{7}$ There is thus much to be gained from international dialogue of the kind that Professor Sunstein's essay invites.

In this co-operative spirit, I would like to engage ("take issue" is too strong a phrase) with certain aspects of Professor Sunstein's reading of Grootboom. The next section attempts to refine his bipartite classification of constitutions into those that are "preservative" and those, like the South African Constitution, ${ }^{8}$ which are best described as "transformative." Although this typology is helpful, the terms "preservative" and "transformative" are perhaps better conceptualized as opposite ends of a continuum of possible constitutions, with some more obviously transformative or preservative than others.

After briefly reiterating the factual background to Grootboom and the reasons given by the court a quo and the Constitutional Court for their decisions, the main part of this response interrogates Professor

\footnotetext{
Ibid.

Compare C. Scott \& P. Alston, "Adjudicating Constitutional Priorities in a Transnational Context: A Comment on Soobramoney's Legacy and Grootboom's Promise" (2000) 16 S. Afr. J. Hum. Rts. 206; and H. Klug, Constituting Democracy: Law, Globalism and South Africa's Political Reconstruction (Cambridge: Cambridge University Press, 2000).

See e.g. the special issue of the South African Journal on Human Rights on the Grootboom decision (v. 17, no. 2, 2001).

8 The Constitution of the Republic of South Africa 1996, Act No. 108 of 1996 [hereinafter South African Constitution].
} 
Sunstein's reading of the Constitutional Court's decision as engaging in "priority-setting." Although it undoubtedly pushes out the boundaries of socioeconomic rights adjudication, the interpretation advanced here is that the decision falls short of obliging the South African government to order its spending priorities in any particular way. Rather, the decision is authority for the more limited proposition that socioeconomic rights of the kind contained in the South African Constitution may require the diversification of social and economic policies so as to cater to vulnerable groups. Although the judicially enforced diversification of a policy will inevitably impact on budgetary allocations, the legislature and the executive retain, on this narrower reading of Grootboom, the power to decide on the temporal order in which social needs are met.

The importance of this narrower reading, which may seem slight at the abstract level, is illustrated through a case study of the South African government's land redistribution policy. That policy has recently shifted away from its original focus on providing land for the rural poor in favour of assisting aspirant commercial farmers. In extrapolating the ratio of the Grootboom decision to test the constitutionality of the new policy, the weakness of the judgment becomes clear. It simply does not go far enough in constraining the state from expending scarce resources on relatively privileged groups for whom such assistance is an added benefit rather than a pressing need.

In conclusion, I return to Grootboom to argue that the flaw in the decision is to be found not so much in the Court's substantive reasoning, but rather in the form of the order made. In failing to back up its declaration of constitutional invalidity with a proper enforcement mechanism, the Court did not do justice to the remedies available under the South African Constitution. To this extent, the decision, though correctly described as "extraordinary," was not extraordinary enough.

\section{A CAUTIONARY NOTE ON THE “TRANSFORMATIVE" CONSTITUTION}

In summarising the debate that preceded the inclusion of socio-economic rights in the South African Constitution, Professor Sunstein draws a distinction between "preservative" constitutions, which "seek to maintain existing practices," and "transformative" constitutions which "set out certain aspirations that are emphatically understood as a challenge to longstanding

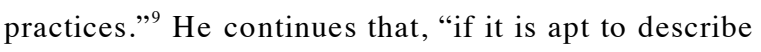
the South African Constitution [as the leading example of a transformative constitution], this is because [it] is designed to ensure that future governments do not fall prey to anything like the evils of the apartheid era." 10 Earlier in this section, the "overriding goal" of the South African Constitution is said to be "a commitment to overcome the legacy of apartheid." ${ }^{11}$ This is probably the better wording, for reasons given below.

The bifurcation of constitutions into those that are "preservative" and those that are "transformative," though useful, is perhaps a little too neat. ${ }^{12}$ Arguably, a constitution that extended civil and political rights (including the right to own property) to all South Africans, but which contained no justiciable socioeconomic rights, would also have had a transformative effect. Yet, such a constitution would not have been "emphatically understood as a challenge to longstanding practices" and would therefore not have been transformative in the absolute sense used by Professor Sunstein. Similarly, a preservative constitution in the South African context could have taken a number of more or less absolute forms. The 1983 South African Constitution, for example, whilst establishing a Tricameral Parliament that for the first time extended political rights to members of the socalled "coloured" and "Indian" groups, nevertheless maintained the white group's effective stranglehold on political power. ${ }^{13}$ A more politically daring constitution at the time might have been one that extended the franchise to all South Africans whilst protecting property rights much more strongly than is the case in the current Constitution, thereby barring the democratic government from pursuing meaningful social reforms. But would such a constitution have been preservative or transformative? 
These examples illustrate that it may be better to conceptualize the terms "preservative" and "transformative" as opposite ends of a continuum of types of constitutions, with some constitutions being more obviously preservative or transformative than others. Perhaps Professor Sunstein means to imply as much when describing the American Constitution as being made up of "a mixture of preservative and transformative features." ${ }^{14}$ A mixed constitution in this sense, however, is not necessarily the same thing as a constitution that occupies a point along a continuum. The American Constitution is mixed because of the practical difficulty of adding to the amendments, meaning that it is a patchwork of different generations' constitutional aspirations, with some missing generations in between. In the result, there is no express commitment either to preserving or to transforming the status quo. Given the chance to start afresh, the American people would probably choose a constitution that was less patchy, and more committed to a coherent set of ideals representing the political centre. Once again, however, such a constitution would neither be preservative nor transformative in any absolute sense.

It is important to get these nuances right. As noted above, in describing the South African Constitution as "the world's leading example of a transformative constitution," 15 Professor Sunstein alternately depicts it as a constitution that aims to prevent the recurrence of apartheid-like evils and one that aims to overcome the legacy of apartheid. There is in fact a crucial difference between these two depictions, with the second more apposite than the first. As the product of time-bound social and economic forces, the policy of apartheid will self-evidently never recur in precisely the same form, with or without a constitutional pre-commitment that forbids future governments from heading in that direction. Perhaps more plausibly it could be said that the current South African Constitution is designed to prevent the recurrence of totalitarianism - for that is, generically, what apartheid was. But why then the need to be so specific? Most constitutions based on the liberal model attempt to do something like this. The better view is surely that the South African Constitution was designed to address the legacy of apartheid, and that justiciable socio-economic rights were seen as integral to that enterprise.

An example of the paradoxical results that may flow from depicting the South African Constitution as being primarily about pre-empting a return to the past rather than addressing a historical legacy is provided by the decision in Betta Eiendomme (Pty) Ltd v. Ekple-

Sunstein, supra note 2 at 125.

15 Ibid.
Epoh. ${ }^{16}$ In this case, the Witwatersrand Local Division of the High Court was asked to rule on whether section 26(3) of the South African Constitution had altered the common-law pleading requirements in an action for ejectment. Before the coming into force of the South African Constitution in February 1996, the common law required that the plaintiff in an action for ejectment allege and prove ownership of the land and lawful termination of the defendant's right of occupation. ${ }^{17}$ Section 26(3), which forms part of the housing right, but which was not at issue in Grootboom, provides: ${ }^{18}$

No one may be evicted from their home, or have their home demolished, without an order of court made after considering all the relevant circumstances. No legislation may permit arbitrary evictions.

In an earlier case, the Cape of Good Hope High Court had held that this provision had indeed altered the common law. Where it is conceded that the land is occupied as the defendant's home, that Court reasoned, the protection afforded by section 26(3) is triggered. In such circumstances, the plaintiff in an action for ejectment must, in addition to the common-law requirements, allege and prove relevant circumstances justifying the granting of an eviction order. ${ }^{19}$

In Betta Eiendomme, the Witwatersrand Local Division, describing section 26(3) as a "never again" provision, declined to follow this ruling. ${ }^{20}$ Instead, it restricted the constitutional requirement that relevant circumstances be considered in situations where the defendant was facing eviction under discriminatory legislation like that applicable in the apartheid era. In this Court's view, section 26(3) had not altered the law applicable to "cases of ordinary trespass, whether in the

16 Betta Eiendomme (Pty) Ltd v. Ekple-Epoh 2000 (4) SA 468 (W) [hereinafter Betta Eiendomme].

17 See Graham v. Ridley 1931 T.P.D. 476 and Chetty v. Naidoo 1974 (3) SA 13 (A).

18 The origins of this provision may be traced to the decision by Goldstone J. in S. v. Govender 1986 (3) SA 969 (T) at $971 \mathrm{H}-\mathrm{J}$ that magistrates, when exercising their discretion under section 46(2) of the Group Areas Act 1966, Act. No. 36 of 1966 to grant an order for eviction against a person who had been convicted of an offence under section 26(1) of that Act, should take into account "circumstances" such as "the personal hardship which such an order may cause and the availability of alternative accommodation."

19 Ross v. South Peninsula Municipality 2000 (1) SA 589 (C) at 599C.

20 High Court judges in South Africa are not bound to follow decisions of judges in other provincial divisions of the High Court, although such decisions (especially Full Bench decisions) are regarded as highly persuasive. See H.R. Hahlo \& E. Kahn, The South African Legal System and its Background (Cape Town: Juta \& Co., 1968) at 251. 
form of squatting or holding over or otherwise." ${ }^{21}$ Since no future South African government is ever likely to reenact discriminatory legislation providing for forced removals, this reading of section 26(3) renders its impact on the common law nugatory.

The point of this example is simply to note the way in which a politically conservative judge can deploy the language of transformation to read down constitutional rights, even where the general thrust of a constitution is "emphatically" transformative. This is trite legal realism, but the point is worth repeating nevertheless. Amongst other things, it reminds us that the transformative potential of a constitution is a function both of the constitutional text and the nature of its community of interpreters. ${ }^{22}$ One of the paradoxes of the South African transition is that the task of realizing the transformative potential of the South African Constitution was given to an overwhelmingly conservative judiciary whose class and race interests are not served by the kind of transformation the South African Constitution envisages. Although the Constitutional Court was created precisely to overcome this problem, its record to date has generally reflected the prevailing ethos of the legal culture in which its members were socialized. ${ }^{23}$ Thus the Court in Grootboom, even as it went further than any other court in the world has gone in giving effect to socioeconomic rights, did not in the end embrace the full extent of the South African Constitution's transformative vision. The argument in support of this claim is the subject of the remainder of this response.

\section{THE DECISION IN GROOTBOOM}

The Grootboom case concerned a group of homeless people, consisting of 390 adults and 510 children, who had been evicted from land earmarked for a low-cost housing project. After their eviction, the community's legal representative wrote to the local

\footnotetext{
Betta Eiendomme, supra note 16 at para. 7.2

22 And other factors, too. See e.g. C.R. Epp, The Rights Revolution: Lawyers, Activists and Supreme Courts in Comparative Perspective (Chicago: University of Chicago Press, 1998) (emphasizing the role of "support structures for legal mobilization" in the rights revolutions in India, the United States, Britain and Canada).

23 On the origins of this tradition, and its interaction with the new constitutional order, see M. Chanock, The Making of South African Legal Culture 1902-1936: Fear, Favour and Prejudice (Cambridge: Cambridge University Press, 2001) at 511-38. For a discussion of the Constitutional Court's record to date, emphasizing its preference for formalistic legal reasoning rather than the value-based, moral reasoning seemingly required by the Bill of Rights, see A. Cockrell, "Rainbow Jurisprudence" (1996) 12 S. Afr. J. Hum. Rts. 1, and I. Currie, "Judicious Avoidance" (1999) 15 S. Afr. J. Hum. Rts. 138.
}

municipality demanding temporary accommodation. ${ }^{24}$ When this demand was not met, the group launched an application in the Cape of Good Hope High Court ${ }^{25}$ for an order compelling the municipality and/or other responsible tiers of government to comply with their obligations under sections 26 and 28 of the Constitution.

\section{Section 26 provides:}

26. (1) Everyone has the right to have access to adequate housing.

(2) The state must take reasonable legislative and other measures, within its available resources, to achieve the progressive realisation of this right.

Section 28 provides:

28. (1) Every child has the right -

(a) $\ldots$

(b) to family care or parental care, or to appropriate alternative care when removed from the family environment;

(c) to basic nutrition, shelter, basic health care services and social services.

The Cape of Good Hope High Court held that section 28(1)(c) conferred on the applicant children an unqualified right to shelter. ${ }^{26}$ In addition, section 28(1)(b) justified the inclusion of these children's parents in an order compelling "the appropriate organ or department of state" to provide shelter to the applicant children and their accompanying parents until such time as the parents were able to provide shelter to the children themselves. ${ }^{27}$ The claim based on section 26 was dismissed, meaning that those members of the community who did not have children received no relief.

4 Grootboom, supra note 1 at para. 11.

25 Proceedings based on Chapter 2 of the South African Constitution, supra note 8, (the Bill of Rights) are typically launched in the High Court, with the appeal lying directly to the Constitutional Court, the highest authority on constitutional matters. In exceptional cases, parties may approach the Constitutional Court directly. See sections 167, 169 and 172(2) of the South African Constitution, ibid.

26 Grootboom v. Oostenberg Municipality and Others 2000 (3) BCLR 277 (C) at 290G-291C.

27 Ibid. at $293 \mathrm{~J}$. 
On appeal to the Constitutional Court, the South African Human Rights Commission ${ }^{28}$ and the Community Law Centre at the University of the Western Cape were admitted to the case as amici curiae. Although the appeal was initially restricted to the lower court's finding with regard to section 28 , arguments on behalf of the amici successfully reopened the claim based on section 26 .

In a lengthy and densely reasoned decision, the Constitutional Court set aside the lower court's order and substituted for it an order declaring the housing program in the area concerned unconstitutional, in light of section 26(2) of the Constitution. The essence of the Court's decision is that this subsection, together with section 26(1), requires the state to devise and implement a comprehensive program aimed at realizing the right of access to adequate housing. The existing program fell short of meeting this obligation "to the extent that it fail[ed] to recognise that the State must provide for relief for those in desperate need." 29

In so finding, the Court rejected an argument on behalf of the amici that General Comment 3 of 1990 issued by the United Nations Committee on Economic, Social and Cultural Rights ${ }^{30}$ was directly applicable to

28 The South African Human Rights Commission is a "state institution supporting constitutional democracy" under Chapter 9 of the South African Constitution, supra note 8. It was established in terms of the Human Rights Commission Act 54 of 1994. Under section 7(1)(e) of that Act, it has the power to "bring proceedings in a competent court or tribunal in its own name, or on behalf of a person or group or class of persons." In the few instances in which the Hum an Rights Commission has exercised this power to date, it has relied on the generous provision for the admission of amici curiae in the rules of the High Court and the Constitutional Court. See rule 16A of the Uniform Rules of Court (High Court Rules) and rule 9 of the Constitutional Court's Rules (available at www.concourt.gov.za/rules.html). In the most controversial case, the Commission applied to be admitted as an amicus curiae at the High Court stage of a constitutional claim involving the distribution of anti-retroviral drugs to pregnant mothers living with HIV/AIDS (Treatment Action Campaign and Others v. Minister of Health and Others (unreported) Transvaal Provincial Division Case 21182/2001 (judgment of Botha J. delivered on 14 December 2001). The Commission subsequently withdrew its application under a cloud of accusations that it had been influenced to do so by the executive. On the monitoring of socio-economic rights by the Commission in terms of section 184(3) of the South African Constitution, supra note 8 , see the Commission's annual Economic and Social Rights Reports (available at www.sahrc.org.za) and the regular updates on the Commission's work in this area published in ESR Review: Economic and Social Rights in South Africa [hereinafter ESR Review].

29 Grootboom, supra note 1 at para. 66.

30 Committee On Economic, Social and Cultural Rights, UN ESCOR, 5th Sess., Annex III, General Comment No. 3 (1990). The Nature of States Parties' Obligations (Art. 2, Para. 1, of the case. Paragraph 10 of this Comment interprets articles 2.1 and 11.1 of the International Covenant on Economic, Social and Cultural Rights ${ }^{31}$ as meaning that state Parties have to devote all the resources at their disposal first to satisfy the "minimum core content" of the right to adequate housing. ${ }^{32}$ Article 2.1 provides:

Each State Party to the present Covenant undertakes to take steps, individually and through international assistance and cooperation, especially economic and technical, to the maximum of its available resources, with a view to achieving progressively the full realization of the rights recognized in the present Covenant by all appropriate means, including particularly the adoption of legislative measures.

Article 11.1 of the Covenant in turn provides:

The States parties to the present Covenant recognize the right of everyone to an adequate standard of living for himself and his family, including adequate food, clothing and housing, and to the continuous improvement of living conditions. The States parties will take appropriate steps to ensure the realization of this right, recognizing to this effect the essential importance of international cooperation based on free consent.

The basis for the Court's refusal to apply these provisions was twofold. First, the Court held that the textual differences between section 26(1) and (2) of the South African Constitution and articles 2.1 and 11.1 of the Covenant, particularly the qualification of the right to adequate housing in the former instance by the word "access" and the difference between "appropriate steps" and "reasonable measures," 33 suggested that "the real question in terms of [the South African] Constitution is whether the measures taken by the State to realise the right afforded by section 26 are reasonable." 34 The minimum core content of the right to adequate housing was just one indicator in respect of this overarching inquiry. In any event, the Court held, there was insufficient evidence before it to allow it to determine

The Covenant), UN Doc. E/1991/23.

31 International Covenant on Economic, Social and Cultural Rights, 16 December 1966, 993 U.N.T.S. 3.

32 South Africa has signed, but not ratified the Covenant. See Grootboom supra note 1 at para. 27 n. 29. However, according to section 39(1) of the South African Constitution, supra note 8 , " $[w]$ hen interpreting the Bill of Rights, a court, tribunal or forum - ... (b) must consider international law."

33 Grootboom, supra note 1 at para. 28.

34 Ibid. at para. 33 
the minimum core content of the right of access to adequate housing, given regional variations in housing requirements and the rural/urban divide. ${ }^{35}$

After analysing the state's housing program under the three headings suggested by the text of sections 26(1) and (2), the Court concluded that the absence of any measures specifically aimed at assisting "people in desperate need," such as the applicants, was unreasonable..$^{36}$ The housing program was accordingly unconstitutional against section $26(2)$ to this extent. ${ }^{37}$

Interestingly, the appeal in respect of the lower court's section $28(1)$ (c) finding was upheld. The essence of the Court's reasoning in this respect is contained in the following passage: ${ }^{38}$

Through legislation and the common law, the obligation to provide shelter in ss. (1)(c) is imposed primarily on the parents or family and only alternatively on the State. The State thus incurs the obligation to provide shelter to those children, for example, who are removed from their families. It follows that s. 28(1)(c) does not create any primary State obligation to provide shelter on demand to parents and their children if children are being cared for by their parents or families.

The intervention by the amici was thus crucial to the outcome of the Grootboom case. Had the argument in relation to section 26 not been re-opened, the case may well have been decided in favour of the state, on the basis of section 28 alone. By re-opening the argument under section 26, the amici gave the Court the opportunity to rule on the import of this section, and hence to make the order of constitutional invalidity described above. ${ }^{39}$

\section{DID THE GROOTBOOM COURT ENGAGE IN PRIORITY-SETTING?}

In his summary of the decision in Grootboom, Professor Sunstein writes: ${ }^{40}$

In short, the Court held that the Constitution required not only a long-term plan to provide low-income shelter, but also a system to

\footnotetext{
Ibid. at paras. 32-33.

Ibid. at para. 66 .

Ibid. at para. 69.

Ibid. at para. 77 .

The precise nature of the order is discussed in greater detail below.

40 Sunstein, supra note 2 at 127.
}

ensure short-term help for people who had no place to live. ... What is most striking about this ruling is the distinctive and novel approach to socio-economic rights, requiring not shelter for everyone, but sensible prioritysetting, with particular attention to the plight of those with the greatest need.

The crucial term in this passage is "priority-setting." It is not expressly defined, but seems to mean something like the relative importance that the state accords to competing social needs. For example, in his discussion of the section 28 challenge, Professor Sunstein attributes the Court's reluctance to interpret this provision as creating absolute rights to the fear that such an approach "would trump even reasonable priority-setting, thus keeping the state from deciding that in view of sharply limited resources, certain needs were even more pressing." 41 The addition of the qualifier "reasonable" in this passage is significant, since it suggests that the state may act unreasonably by according the wrong degree of importance to competing social needs. It also suggests that it is legitimate, from the point of view of democratic theory, that a court should be able to review and set aside such a policy choice.

This understanding of the term "priority-setting" is sufficient to justify Professor Sunstein's claim that the decision in Grootboom pushes out the boundaries of socio-economic rights adjudication beyond a point that many commentators believed possible. However, there is another sense of the term "priority-setting" that is worth highlighting for what it reveals about the terrain that the Court was not prepared to chart. In its strict sense, I want to suggest that "priority-setting" means the temporal order in which government chooses to meet competing social needs. ${ }^{42}$ The difference between this sense of the term and the sense used by Professor Sunstein was central to the Grootboom case - not because the Court's decision on the constitutionality of the government's housing program would have been any different (the program was unreasonable in both senses), but because the Court's reluctance to engage in priority-setting in the strict sense affected the nature of the order made.

\footnotetext{
Ibid. at 130 .

${ }^{42}$ The Concise Oxford Dictionary of Current English, 7th ed., s.v. "prior" as meaning "earlier; coming before in time, order, or importance," and "priority" as "being earlier or antecedent; precedence in rank etc.; an interest having prior claim to consideration."
} 
I shall return to the nature of the order in conclusion. For the moment, it is sufficient to note that the Court, in declaring the housing program unconstitutional because it did not cater for people in desperate need, did not intrude onto the terrain of "priority-setting" in the strict sense. To be sure, the Court found that it was unreasonable to have a longterm housing strategy in the absence of a short-term relief strategy, ${ }^{43}$ but the reference to temporal sequencing in this part of the decision is deceptive. The Court crucially did not hold, as the legal representative for the amici curiae asked it to, that the state's shortterm relief strategy should take precedence in time over the long-term housing strategy. Rather, the ruling was that the two strategies should be pursued in tandem, with the short-term relief strategy catering for the needs of those without access to shelter, however rudimentary, pending the staged delivery of adequate housing for all.

As Professor Sunstein notes, ${ }^{44}$ the Grootboom decision also stops short of telling the state what proportion of its housing budget should be spent on addressing the plight of people in desperate need. The relevant passage in Grootboom reads: "It is essential that a reasonable part of the national housing budget be devoted to this, but the precise allocation is for the national government to decide in the first instance. ${ }^{45} \mathrm{In}$ this respect, too, rather than setting priorities, the Court in Grootboom simply expressed a view on what could not reasonably be left out of the housing program.

Assuming the South African government takes the decision in Grootboom seriously, it will have inevitable budgetary implications. But it will not impact on the temporal order in which competing needs are met. Only the wholesale adoption of paragraph 10 of the U.N. Committee on Economic, Social and Cultural Rights' General Comment $3^{46}$ would have done that, since this would have required the State first to devote all available resources to meeting the needs of those without any kind of shelter, before moving on to improving the living conditions of everyone. However, as noted above, the Constitutional Court carefully distinguishes the text of section 26 of the Constitution from articles 11.1 and 2.1 of the International Covenant on Economic, Social and Cultural Rights, precisely so as to avoid this result.

\footnotetext{
Grootboom, supra note 1 at paras. 65-66.

Sunstein, supra note 2 at 131.

Grootboom, supra note 1 at para. 66

Supra note 30.
}

\section{THE EXAMPLE FROM LAND REFORM}

The significance of this narrower reading of Grootboom may be illustrated by a hypothetical case testing the constitutionality of a recent shift in the South African government's land redistribution policy. In its initial form, as part of the African National Congress's 1994 election manifesto, the policy recognized the need to provide "residential and productive land to the poorest section of the rural population and aspirant farmers." ${ }^{47}$ In the subsequent White Paper on South African Land Policy, ${ }^{48}$ however, a clear choice was made in favour of the role of land redistribution in poverty alleviation. This emphasis was confirmed in the implementation of the policy, where the focus fell on the award of Settlement Land Acquisition Grants of $\mathrm{R} 15,000$ (later increased to R 16,000) to people falling below a threshold income of R1,500 per month.

In June 2000, a year after the appointment of a new Minister of Agriculture and Land Affairs, land redistribution policy in South Africa took a decisive turn with the publication of an "Integrated Programme of Land Redistribution and Agricultural Development." 49 One of the express aims of the new policy is to assist people from historically disadvantaged groups to become commercial farmers. This objective is pursued through a sliding-scale system of grants, from a minimum of R20,000 (accessed via a self-contribution in cash, materials or labour of $\mathrm{R} 5,000$ ) up to R100,000 (accessed via a self-contribution of $\mathrm{R} 400,000)$.

The total budget for land reform has not, however, significantly increased. An inevitable consequence of the new policy is thus that resources will be diverted away from funding grants to the rural poor towards funding grants to the relatively well off. The main nongovernmental organization representing the rural poor, the National Land Committee (NLC), has criticized the new policy on precisely these grounds. ${ }^{50}$ As a simple matter of arithmetic, each grant made at the upper end of the scale is equivalent to five grants made at the entry-level. The new policy therefore presumptively prejudices poor people in the absence of a significant increase in the total overall budget for land redistribution.

\footnotetext{
47 African National Congress, The Reconstruction and Development Programme: A Policy Framework (Johannesburg: Umanyano Publications, 1994) at para. 2.4.3 [emphasis added]. 48 Department of Land Affairs (April 1997).

49 Ministry of Agriculture and Land Affairs (June 2000).

50 National Land Committee, "Workshop Briefing Paper" delivered at the Civil Society Forum on Land \& Agrarian Reform, Johannesburg (22-23 August 2000) at 11.
} 
The NLC has expressed the view that the new policy is "at variance with government's constitutional obligation to implement a wide-ranging land redistribution programme," ${ }^{51}$ but has not formally announced that it intends to mount a legal challenge to this effect. Depending on the success of its attempts to lobby government to amend the policy, such a challenge may become the only option available to it.

Like the housing policy, land redistribution policy in South Africa is subject to a justiciable socioeconomic right. Section 25(5) of the Constitution provides: ${ }^{52}$

The state must take reasonable legislative and other measures, within its available resources, to foster conditions which enable citizens to gain access to land on an equitable basis.

Because of the textual similarity between this provision and section 26 , land reform activists, along with their colleagues in the health and welfare sectors, eagerly awaited the outcome of the constitutional challenge to the housing program in Grootboom. A farreaching judgment in this case would, it was thought, open the door to litigation in other sectors similarly subject to justiciable socio-economic rights. When the initial euphoria over the decision subsided, however, a mood of disappointment set in. Although welcoming the declaration of constitutional invalidity, many realized that the Court had stopped short of making the robust order that had widely been anticipated. ${ }^{53}$

From the point of view of activists working in the land reform sector, the reasons for this disappointment are readily apparent from an examination of the new land redistribution policy against section 25(5), interpreted according to the standard of review laid down in Grootboom. The major difference between the right of access to adequate housing and the right of access to land is that the state's primary duty in the

\footnotetext{
Ibid. at 2 .

2 The "right of access to land" in section 25(5) was included among the list of justiciable socio-economic rights given by the Court in Grootboom, supra note 1 at para. 19, n. 15.

53 On 18 May 2000, one week after the Grootboom case was heard in the Constitutional Court, the President of the Court, Arthur Chaskalson, delivered a public lecture in which he said that South Africans had "temporarily ... lost [their] way" in realizing the constitutional vision of "[a] society in which there will be social justice and respect for human rights, a society in which the basic needs of all ... people will be met" A. Chaskalson, "Human Dignity as a Foundational Value of Our Constitutional Order" (2000) 16 S. Afr. J. Hum. Rts. 193 at 205. This remark was widely interpreted at the time as a sign that the Court would use the Grootboom case to hold the executive to account on the slow pace of social service delivery.
}

latter case is simply "to foster conditions which enable citizens to gain access to land." This difference aside, however, the structure of the two provisions is essentially the same. Thus the standard of review in section 25(5), like that in section $26(2)$, is the "reasonableness" of the "legislative and other measures" taken by the state to fulfill its constitutional obligation, qualified by the availability of resources.

Suppose that the NLC were to challenge the new land redistribution policy on the grounds that it will inevitably divert resources away from the rural poor to the relatively well off. In order to succeed, the NLC would have to convince the Court that the state had unreasonably failed, taking into account its available resources, to adopt legislative and other measures to foster conditions that enabled citizens to gain access to land on an equitable basis. The NLC could try to do this by arguing that it is not reasonable for the State to award grants of R100,000 to people who are able to raise $\mathrm{R} 400,000$ of their own capital. In relation to such people, the NLC might plausibly argue, the state's duty is to ensure that ordinary commercial loans are available. To this end, the NLC might rely on the dictum in Grootboom that the housing policy should take account of "different economic levels": ${ }^{54}$

For those who can afford to pay for adequate housing, the State's primary obligation lies in unlocking the system, providing access to housing stock and a legislative framework to facilitate self-built houses through planning laws and access to finance. Issues of development and social welfare are raised in respect of those who cannot afford to provide themselves with housing.

This dictum, one might think, becomes all the more forceful in relation to a right that expressly obliges the state to "foster conditions" facilitating "access to" the economic good in question. Moreover, the reference to equity in section 25(5) seems to imply that land redistribution policy, in addition to being reasonable, must also be fair.

On the evidence of Grootboom, the Court would probably approach these issues by carefully distinguishing the text of section 25(5) from section 26(2). The three constituent elements of section 26(2) are considered separately in Grootboom at paragraphs 39 to 46 . The duty to adopt "reasonable legislative and other measures" is said to involve primarily the allocation of responsibilities to different spheres of

54 Grootboom, supra note 1 at para. 36. 
government. ${ }^{55}$ It also means, however, that the policy must be theoretically capable of realizing the right in question, though not the only way, ${ }^{56}$ and that the implementation strategy itself must be reasonable. ${ }^{57}$ In a particularly interesting passage under this heading, the Court remarks that "[a] program that excludes a significant segment of society cannot be said to be reasonable." ${ }^{58}$ The next paragraph, however, appears to restrict this statement to vulnerable segments of society: "Those whose needs are the most urgent and whose ability to enjoy all rights therefore is most in peril, must not be ignored by the measures aimed at achieving realisation of the right." ${ }^{, 59}$

In the NLC's hypothetical constitutional challenge, these dicta invite an analysis of the institutional mechanisms used to implement the new land redistribution policy, and of their impact in practice. At this level of generality, and at this point in time, the NLC would not succeed in challenging the policy on these grounds. As in the housing sector, a fairly sophisticated legal framework for land redistribution is now in place. ${ }^{60}$ The new land redistribution policy does not envisage any change to this framework, although a more significant devolution of responsibilities to provincial level is contemplated, together with greater co-operation between different government agencies. It is also too early to question the implementation of the new policy. Initial indications are, however, that there has been a tremendous slow-down in the number of land redistribution projects approved since the change to a sliding-scale system of grants. ${ }^{61}$

Can the new land redistribution policy be challenged on the ground that it does not cater to a "significant segment of society"? This question reveals a crucial ambiguity in the Grootboom decision that is worth exploring in more detail. As noted above, the Court at first appears to say that a program that excludes any "significant segment of society" will be

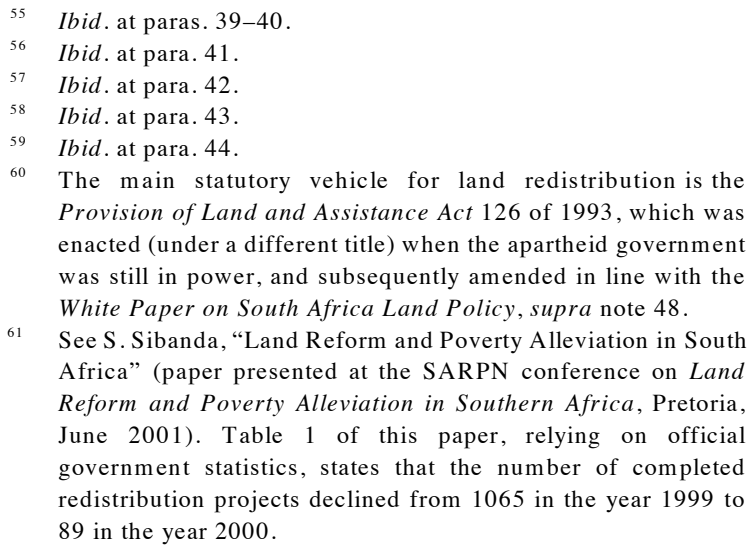

${ }_{61}$ See S. Sibanda, "Land Reform and Poverty Alleviation in South Africa" (paper presented at the SARPN conference on Land Reform and Poverty Alleviation in Southern Africa, Pretoria, June 2001). Table 1 of this paper, relying on official government statistics, states that the number of completed redistribution projects declined from 1065 in the year 1999 to 89 in the year 2000 .

unreasonable..$^{62}$ In the next paragraph, however, the Court qualifies this remark by stressing that special attention should be paid to " $[\mathrm{t}]$ hose whose needs are the most urgent and whose ability to enjoy all rights therefore is most in peril." And, of course, the Court's eventual declaration of constitutional invalidity is directed at the housing program's failure to cater "for those in desperate need." ${ }^{63}$

In the result, the question whether a particular segment of society is constitutionally "significant" appears to depend on its degree of vulnerability, i.e. on how pressing its needs are. It is for this reason that Professor Sunstein is correct to argue that the Court engages in priority-setting in a weak sense. But the required standard is merely inclusion - a government program that is subject to socio-economic rights will be unreasonable if it fails to cater to a significant segment of society. Nothing is said about how the state ought to apportion its efforts between competing significant segments or, more importantly, between significant and not-so-significant segments of society.

It follows that the NLC would find very little purchase for an argument that, in diverting resources away from the rural poor, the new land redistribution policy violated the "reasonable legislative and other measures" requirement of section 25(5). Provided that the rural poor are catered to in some way, as they are at the bottom end of the sliding scale, such a change in policy is, it would seem, constitutionally permissible.

The second element of the Court's compartmentalized analysis of section 26(2) in Grootboom, the state's duty progressively to realize the right, would be irrelevant to a challenge based on section 25(5) since this element does not appear in that provision. This difference is particularly unfortunate for the NLC because it was here that the Court in Grootboom was most sympathetic to the principles enunciated in General Comment 3. Noting that the phrase "progressive realisation" is "taken from international law and art 2.1 of the Covenant in particular," the Court held that "there is no reason not to accept that it bears the same meaning in the Constitution as in the document from which it was so clearly derived." ${ }^{\circ 4}$ By this device, the Court was able to hold that the principles laid down in paragraph 9 of General Comment 3 were directly applicable to section 26(2), including the important principle that

\footnotetext{
Grootboom, supra note 1 at para. 43.

Ibid. at para. 66.

Ibid. at para. 45 .
} 
"deliberately retrogressive measures" are impermissible. ${ }^{65}$

Had section 25(5) imposed a duty on the state to realize progressively the right of access to land, this part of the Grootboom decision may have provided a basis on which to challenge the new land redistribution policy. At first blush, the move from a flat-rate, income-related system of grants to a sliding-scale, income-independent system is a deliberately retrogressive measure, certainly from the point of view of the rural poor. This conclusion depends, however, on the assumption that emerging commercial farmers are not a "significant segment of society" equally deserving of respect and concern. On the narrower reading of Grootboom proposed above, it is not self-evident that a decision to diversify a social program so as to cater to a more affluent segment of society is a "deliberately retrogressive" step. Indeed, it may be a constitutionally necessary step in order to include a segment of society that was previously not catered to.

The reference to "available resources" in section 25(5), which is repeated in section 26(2), also does not assist the NLC. The Court's specific treatment of this element in Grootboom is limited to one paragraph, half of which is devoted to repeating the position adopted in a previous case, i.e. that the reference to "available resources" must be understood as an internal limitation qualifying the state's duty to realize the right in question. ${ }^{66}$ Given its refusal earlier on in the judgment to apply the U.N. Committee on Economic, Social and Cultural Rights' concept of minimum core obligations, the Court's cursory treatment of the "available resources" element is not surprising. Yet, in a country with scarce resources, the temporal order in which resources are deployed by the State is the key question. By declining to intrude onto this terrain, the Court in Grootboom left the most important policy issues for decision by the legislature and the executive. In the hypothetical test case, the consequence of this judicial self-restraint is that the NLC will almost certainly fail were it to challenge the decision to divert land redistribution resources away from the rural poor. Provided that some resources are still being made available to the rural poor - a "reasonable" proportion (whatever that may mean) - the policy will pass constitutional muster.

65 Ibid.

$66 \quad$ Ibid. at para. 46.

\section{CONCLUSION}

The example from land reform illustrates why activists working in areas related to the housing sector were more than a little disappointed with the Grootboom decision. It simply does not provide the sort of legal ammunition that many of them had hoped for. The most positive aspect of the decision is the ruling that, in order to survive constitutional impugnment, a social program must not only be reasonably designed, but also reasonably implemented. The direct application of paragraph 9 of General Comment $3^{67}$ is also significant for people working in sectors where the state is under a duty progressively to realize the right in question.

Even these aspects of the decision, however, are ultimately dependent on the strength of the mechanisms used to enforce socio-economic rights. It is in this respect that the decision was most disappointing. The Court's final order is worth quoting in full for what it reveals about the Court's preparedness to hold the legislative and executive arms of government to account for their constitutional obligations:

1. The appeal is allowed in part.

2. The order of the Cape of Good Hope High Court is set aside and the following order is substituted for it:

'It is declared that:

(a) Section 26(2) of the Constitution requires the State to devise and implement within its available resources a comprehensive and coordinated program progressively to realise the right of access to adequate housing.

(b) The program must include reasonable measures ... to provide relief for people who have no access to land, no roof over their heads, and who are living in intolerable conditions or crisis situations.

(c) As at the date of the launch of this application, the State housing program in the area of the Cape Metropolitan Council fell short of compliance with the requirements in para $(b)$, in that it failed to make reasonable provision within its available resources for people in the Cape Metropolitan area with no access to land, no roof over their

$67 \quad$ Supra note 30 
heads, and who were living in intolerable conditions or crisis situations.

3. There is no order as to costs. ${ }^{68}$

The substituted order is entirely declaratory. ${ }^{69}$ Paragraph (a) merely restates the provisions of section 26(2). Paragraph (b) confirms that the state's constitutional duty is to "include" a particularly vulnerable segment of society in its housing program, without necessarily prioritizing its efforts to meet this group's needs. Finally, paragraph (c) restricts the declaration of invalidity to the particular geographic area at issue in the Grootboom case, as though what is said in the decision about the deficiencies of the national housing program had no bearing on the lack of an effective program at the local level.

No doubt political scientists interested in the Court's quest for legitimacy will have much to say about this studied exercise in judicial deference, ${ }^{70}$ but the message for public-impact litigators is clear: don't get your hopes up. The closest the Court came to giving its order teeth was the observation that the South African Human Rights Commission was under a constitutional duty to monitor the promotion of socioeconomic rights, and would thus, "if necessary ... report on the efforts made by the State to comply with its section 26 obligations in accordance with this judgment." ${ }^{71}$ In short, the Court appears to take the view that an adequate mechanism for the enforcement of socio-economic rights already exists, and that its role is simply to give guidance to the Human Rights Commission on the proper interpretation of the Constitution .

An indication of how far this position was from meeting the expectations of other members of the South African Constitution's community of interpreters may be gleaned from the range of remedies considered by a leading constitutional litigator in a paper delivered two years before the decision in Grootboom was handed down. Noting that section 172(1)(b) of the Constitution gives the courts "sweeping powers ... to develop and build their own arsenal of remedies," Wim Trengove suggests that an order consequent on a finding that a

68 Grootboom, supra note 1 at para. 99

69 Compare the very detailed order granted in the lower court decision, supra note 26 at $293 \mathrm{H}-294 \mathrm{C}$.

70 For an analysis of the Constitutional Court's record before Grootboom from this perspective, see S. Gloppen, South African Constitutionalism 1994-2000: The difficult balancing act of the Constitutional Court (Doctoral Dissertation, Department of Comparative Politics, University of Bergen 2000) [unpublished].

71 Grootboom, supra note 1 at para. 97. socio-economic right has been violated might include a direction to the relevant state agency that it present the Court "with a plan of reform which would put an end to the violation." "72 After approving the means-end rationality of the plan, the Court might then order the agency to implement it according to predetermined deadlines. ${ }^{73}$ Trengove even goes so far as to suggest that the Court should write the plan for the agency if it unreasonably fails to do so itself, and that it should hold individual state officials in contempt of court if they fail to perform. $^{74}$

One does not have to accept that all of these remedies are justifiable from the point of view of democratic theory to appreciate the extent of the road not travelled by the Court in Grootboom. At the very least, it should have ordered the appellants to return at a later date with a plan detailing how they intended to cater to people with "no access to land, no roof over their heads, and who are living in intolerable conditions or crisis situations." 75 In the absence of such an enforcement mechanism, the Court's declaration of constitutional invalidity has embarrassment value only. Assuming it is correct to describe this remedy as one emanating from administrative law, it is a remedy without a sanction, and therefore without any practical relevance for people whose socio-economic rights constitute their sole claim to citizenship. ${ }^{76}$

\section{Theunis Roux}

Senior Researcher, Centre for Applied Legal Studies, University of the Witwatersrand.

72 W. Trengove, "Judicial Remedies for Violations of SocioEconomic Rights" (1999) 1 E.S.R. Rev. 8 at 10

73 Ibid.

74 Ibid.

75 Grootboom, supra note 1 at para. 99.

76 On 2-3 May 2002 the Constitutional Court will consider an appeal from the decision of the Transvaal High Court in the Treatment Action Campaign case, supra note 28 . The order in this case comes much closer to the type of order suggested by Trengove. Paragraph 4 of the order, for example, enjoins the respondents "forthwith to plan an effective comprehensive national programme to prevent or reduce the mother-to-child transmission of HIV, including the provision of voluntary counselling and testing, and where appropriate, Nevirapine or other appropriate medicine, and formula milk for feeding, which programme must provide for its progressive implementation to the whole of the Republic, and to implement it in a reasonable manner." Paragraph 5 enjoins each of the respondents to deliver a report within three months on "what he or she has done to implement the order in paragraph 4" and detailing "what further steps he or she will take to implement the order in paragraph 4 , and when he or she will take each such step." Clearly, the Constitutional Court's judgment on appeal in this matter will reveal a great deal about its preparedness to move beyond the limits of the declaratory order granted in Grootboom to the range of supervisory orders suggested by Trengove. 